\title{
Weight Gain after Lung Reduction Surgery Is Related to Improved Lung Function and Ventilatory Efficiency
}

\author{
Victor Kim1, Dana M. Kretschman1, Alice L. Sternberg2, Malcolm M. DeCamp, Jr. ${ }^{3}$, and \\ Gerard J. Criner ${ }^{1}$; on behalf of the National Emphysema Treatment Trial Research Group* \\ ${ }^{1}$ Division of Pulmonary and Critical Care Medicine, Temple University School of Medicine, Philadelphia, Pennsylvania; ${ }^{2}$ Johns Hopkins Bloomberg \\ School of Public Health, Baltimore, Maryland; and ${ }^{3}$ Division of Thoracic Surgery, Northwestern University Feinberg School of Medicine, Chicago, \\ Illinois
}

\begin{abstract}
Rationale: Lung volume reduction surgery (LVRS) is associated with weight gain in some patients, but the group that gains weight after LVRS and the mechanisms underlying this phenomenon have not been well characterized.

Objectives: To describe the weight change profiles of LVRS patients enrolled in the National Emphysema Treatment Trial (NETT) and to correlate alterations in lung physiological parameters with changes in weight.

Methods: We divided 1,077 non-high-risk patients in the NETT into groups according to baseline body mass index (BMI): underweight $\left(<21 \mathrm{~kg} / \mathrm{m}^{2}\right)$, normal weight $\left(21-25 \mathrm{~kg} / \mathrm{m}^{2}\right)$, overweight $(25-30 \mathrm{~kg} /$ $\left.\mathrm{m}^{2}\right)$, and obese $\left(>30 \mathrm{~kg} / \mathrm{m}^{2}\right)$. We compared BMI groups and LVRS and medical groups within each $B M I$ stratum with respect to baseline characteristics and percent change in $\mathrm{BMI}(\% \Delta \mathrm{BMI})$ from baseline. We examined patients with $(\triangle \mathrm{BMI} \geqslant 5 \%)$ and without $(\triangle \mathrm{BMI}<5 \%)$ significant weight gain at 6 months and assessed changes in lung function and ventilatory efficiency $\left(\dot{\mathrm{V}} \mathrm{E} / \dot{\mathrm{V}} \mathrm{CO}_{2}\right)$.

Measurements and Main Results: The percent change in BMI was greater in the LVRS arm than in the medical arm in the underweight and normal weight groups at all follow-up time points, and at 12 and 24 months in the overweight group. In the LVRS group, patients with $\triangle \mathrm{BMI} \geqslant 5 \%$ at 6 months had greater improvements in $\mathrm{FEV}_{1}(11.53 \pm 9.31$ vs. $6.58 \pm$ $8.68 \% ; P<0.0001)$, FVC (17.51 \pm 15.20 vs. $7.55 \pm 14.88 \% ; P<0.0001)$, residual volume $(-66.20 \pm 40.26$ vs. $-47.06 \pm 39.87 \% ; P<0.0001), 6-$ minute walk distance ( $38.70 \pm 69.57$ vs. $7.57 \pm 73.37 \mathrm{~m} ; P<0.0001)$, maximal expiratory pressures $(12.73 \pm 49.08$ vs. $3.54 \pm 32.22 ; P=$ $0.0205)$, and $\dot{\mathrm{V}}_{\mathrm{E}} / \dot{\mathrm{V}}_{\mathrm{CO}}(-1.58 \pm 6.20$ vs. $0.22 \pm 8.20 ; P=0.0306)$ at 6 months than patients with $\Delta \mathrm{BMI}<5 \%$ at 6 months.

Conclusions: LVRS leads to weight gain in nonobese patients, which is associated with improvement in lung function, exercise capacity, respiratory muscle strength, and ventilatory efficiency. These physiological changes may be partially responsible for weight gain in patients who undergo LVRS.
\end{abstract}

Keywords: pulmonary disease; chronic obstructive; lung volume reduction surgery; ventilatory efficiency; cachexia

\footnotetext{
(Received in original form March 23, 2012; accepted in final form July 30, 2012)

*A complete list of members, participating clinical centers, and other participants may be found before the beginning of the REFERENCES.

The National Emphysema Treatment Trial (NETT) is supported by contracts with the National Heart, Lung, and Blood Institute (N01HR76101, N01HR76102, N01HR76103, N01HR76104, N01HR76105, N01HR76106, N01HR76107, N01HR76108, N01HR76109, N01HR76110, N01HR76111, N01HR76112, N01HR76113, N01HR76114, N01HR76115, N01HR76116, N01HR76118, and N01HR76119), the Centers for Medicare and Medicaid Services (CMS), and the Agency for Healthcare Research and Quality (AHRQ).
}

Author Contributions: All authors contributed to the conception, design, data analysis, and interpretation of this manuscript.

Correspondence and requests for reprints should be addressed to Victor Kim, M.D., 785 Parkinson Pavilion, 3401 North Broad Street, Philadelphia, PA 19140. E-mail: victor.kim@tuhs.temple.edu

Am J Respir Crit Care Med Vol 186, Iss. 11, pp 1109-1116, Dec 1, 2012 Copyright $\odot 2012$ by the American Thoracic Society

Originally Published in Press as DOI: 10.1164/rccm.201203-05380C on August 9, 2012 Internet address: www.atsjournals.org

\section{AT A GLANCE COMMENTARY}

Scientific Knowledge on the Subject

Lung volume reduction surgery results in greater exercise capacity, improved lung function, and a reduction in mortality in selected patients with advanced emphysema compared with medical therapy. The impact of lung volume reduction surgery on body mass index has not been well described.

\section{What This Study Adds to the Field}

This study shows that underweight patients who underwent lung volume reduction surgery experienced significant improvements in body mass index, and that weight gain after lung volume reduction surgery was related to improved lung function and ventilatory efficiency. These physiological changes may be partially responsible for weight gain in patients who undergo lung volume reduction surgery.

Chronic obstructive pulmonary disease (COPD) is an inflammatory lung disease with many associated comorbid disorders, including coronary heart disease, osteoporosis, metabolic syndrome, and low body mass index (BMI) $(1,2)$. The abnormal local inflammatory response to cigarette smoke leads to airflow obstruction and also results in systemic inflammation, characterized by increased levels of IL-6, IL-8, tumor necrosis factor (TNF)- $\alpha$, and C-reactive protein (3); this systemic inflammation is believed to be responsible for accelerated bone loss, premature development of atherosclerotic heart disease, and skeletal muscle apoptosis $(1,2)$. A low BMI is also a result of several other factors, including breathlessness while eating, difficulty preparing meals because of breathlessness, derangement of glycolipemic hormone metabolism, higher resting energy expenditure from increased work of breathing, physical deconditioning, and respiratory cachexia (4-6).

Low BMI has been shown to be a risk factor for mortality in COPD, both independently as well as a part of a multidimensional index (7-9). Lung volume reduction surgery (LVRS) has been shown to decrease mortality in select patients with advanced emphysema (10) and may improve systemic inflammation and nutritional status $(6,11)$. In whom LVRS will cause weight gain and the mechanisms responsible are currently not well characterized.

We sought to describe the weight change profiles of LVRS patients enrolled in the National Emphysema Treatment Trial (NETT). We also correlated alterations in lung physiological parameters with changes in weight. We hypothesized that patients who were more underweight would gain more weight after LVRS, and that weight gain would be associated with improvements in lung function and ventilatory efficiency. Some of these data were 
reported in an abstract at the 2009 American Thoracic Society International Conference (12).

\section{METHODS}

\section{Patient Selection}

Enrollment criteria for NETT have been previously described (10). All patients provided written informed consent, and the study was approved by the institutional review board at each center. Inclusion criteria included a physical examination consistent with emphysema, radiographic evidence of bilateral emphysema on high-resolution computed tomography (HRCT) scan, $\mathrm{FEV}_{1}$ not exceeding $45 \%$ predicted, but at least $15 \%$ of predicted if age 70 years or older, total lung capacity (TLC) equal to or greater than $100 \%$ predicted, RV equal to or greater than $150 \%$ predicted, $\mathrm{PCO}_{2}$ not greater than $60 \mathrm{~mm} \mathrm{Hg}, \mathrm{Po}_{2}$ equal to or greater than $45 \mathrm{~mm} \mathrm{Hg}$ on room air, and a postrehabilitation 6-minute walk distance greater than $140 \mathrm{~m}$. Patients also needed to be stable on not more than $20 \mathrm{mg}$ of prednisone per day, nonsmoking for 4 months, and have a BMI not greater than $31.1 \mathrm{~kg} / \mathrm{m}^{2}$ in men and not greater than $32.3 \mathrm{~kg} / \mathrm{m}^{2}$ in women. All patients underwent $6-10$ weeks of pulmonary rehabilitation, and then were randomized to either LVRS or continued medical therapy per American Thoracic Society guidelines. Baseline measurements of pulmonary function, 6-minute walk distance, and healthrelated quality of life obtained from the St. George's Respiratory Questionnaire (SGRQ) were obtained after completing pulmonary rehabilitation but before randomization, and again at $6,12,24$, and 36 months.

Patients considered at high risk for LVRS (13) were excluded, and one additional patient without BMI data at baseline was excluded. We divided the remaining 1,077 non-high-risk patients into four groups based on baseline BMI (after pulmonary rehabilitation and before randomization to either LVRS or medical therapy): underweight $\left(<21 \mathrm{~kg} / \mathrm{m}^{2}\right)$, normal weight $\left(21-25 \mathrm{~kg} / \mathrm{m}^{2}\right)$, overweight $\left(25-30 \mathrm{~kg} / \mathrm{m}^{2}\right)$, and obese $\left(>30 \mathrm{~kg} / \mathrm{m}^{2}\right)$. We compared the BMI groups with respect to baseline characteristics. We also stratified on BMI group and compared the LVRS and medical groups with respect to baseline characteristics and percent change in BMI (\% $\% \mathrm{BMI})$ from baseline to follow-up at $6,12,24$, and 36 months.

Stratifying by treatment arm, those with significant weight gain from baseline to 6 months (an increase in $\mathrm{BMI} \geqslant 5 \%, \Delta \mathrm{BMI} \geqslant 5 \%$ ) were compared with those without significant weight gain (no change, a decrease, or an increase in $\mathrm{BMI}<5 \%, \Delta \mathrm{BMI}<5 \%$ ) with respect to changes from baseline to 6 months in lung function, SGRQ score, ventilatory efficiency, and 6-minute walk distance. $\Delta \mathrm{BMI}$ equal to or greater than $5 \%$ was chosen as significant because of existing data suggesting that a change in BMI of $5 \%$ is clinically significant $(14,15)$. Ventilatory efficiency was defined as the ratio of minute ventilation ( $\left.\dot{\mathrm{V}}_{\mathrm{E}}\right)$ to carbon dioxide production $\left(\dot{\mathrm{V}}_{\mathrm{CO}_{2}}\right)$ (16) during unloaded pedaling (chosen as an iso-study time point) during incremental cardiopulmonary exercise testing. Change in diffusing capacity of carbon monoxide $\left(\mathrm{DL}_{\mathrm{CO}}\right)$ was assessed at 12 months because this lung function parameter was not assessed at 6 months.

\section{Statistical Analysis}

Statistics were performed with JMP 8.0 (SAS, Cary, NC) or SAS 9.2 (SAS). Descriptive statistics are reported as means $\pm \mathrm{SD}$, except where otherwise noted. A $P$ value less than 0.05 was considered statistically significant. An unpaired $t$ test was used to compare baseline demographic and pulmonary function data between BMI groups and between LVRS and medical patients. In each BMI group, LVRS and medical patients were compared on $\% \Delta \mathrm{BMI}$ from baseline to each follow-up time point, using unpaired $t$ tests. Within each treatment group, changes in lung function, ventilatory efficiency, 6-minute walk distance, and SGRQ scores were compared between those with $\triangle \mathrm{BMI}$ equal to or greater than $5 \%$ and those with $\triangle \mathrm{BMI}$ less than $5 \%$, using unpaired $t$ tests. Multivariate logistic regression was performed to assess the independent effects of treatment arm (LVRS vs. medical therapy), sex, and baseline exercise category (low vs. high exercise), BMI group, lung function, and $\dot{\mathrm{V}} /$ $\dot{\mathrm{V}}_{\mathrm{CO}_{2}}$ on $\Delta \mathrm{BMI}$ equal to or greater than $5 \%$ at 6 months.

\section{RESULTS}

There were 182, 391, 391, and 113 patients in the underweight, normal weight, overweight, and obese BMI groups, respectively (total $\mathrm{n}=1,077$ ). Baseline data are listed in Table 1. Racial distribution was not different between BMI groups. The underweight group was composed of fewer males compared with the normal weight and overweight groups (45 vs. $62,65 \%$, respectively; both $P<0.05$ ). The underweight group had lower percent

TABLE 1. BASELINE CHARACTERISTICS OF PATIENTS IN EACH BODY MASS INDEX STRATUM

\begin{tabular}{|c|c|c|c|c|c|c|c|c|c|c|c|c|}
\hline & \multicolumn{3}{|c|}{ Underweight (BMI < 21) } & \multicolumn{3}{|c|}{ Normal Weight (BMI 21-25) } & \multicolumn{3}{|c|}{ Overweight (BMI 25-30) } & \multicolumn{3}{|c|}{ Obese (BMI > 30) } \\
\hline & $\begin{array}{c}\text { All } \\
(n=182)\end{array}$ & $\begin{array}{c}\text { LVRS } \\
(n=97)\end{array}$ & $\begin{array}{c}\text { MED } \\
(n=85)\end{array}$ & $\begin{array}{c}\text { All } \\
(n=391)\end{array}$ & $\begin{array}{c}\text { LVRS } \\
(n=207)\end{array}$ & $\begin{array}{c}\text { MED } \\
(n=184)\end{array}$ & $\begin{array}{c}\text { All } \\
(n=391)\end{array}$ & $\begin{array}{c}\text { LVRS } \\
(n=176)\end{array}$ & $\begin{array}{c}\text { MED } \\
(n=215)\end{array}$ & $\begin{array}{c}\text { All } \\
(n=113)\end{array}$ & $\begin{array}{c}\text { LVRS } \\
(n=158)\end{array}$ & $\begin{array}{c}\text { MED } \\
(n=55)\end{array}$ \\
\hline Age, yr & $68 \pm 6^{*}$ & $68 \pm 6$ & $68 \pm 5$ & $68 \pm 6^{*^{\dagger}}$ & $67 \pm 7$ & $67 \pm 6$ & $67 \pm 6$ & $67 \pm 7$ & $67 \pm 7$ & $66 \pm 6$ & $66 \pm 6$ & $66 \pm 6$ \\
\hline Sex, \% male & $45^{\dagger \neq}$ & 38 & 52 & 62 & 60 & 64 & 65 & 64 & 66 & 57 & 50 & 64 \\
\hline Race, \% white & 93 & 93 & 94 & 94 & 96 & 92 & 96 & 96 & 96 & 96 & 97 & 96 \\
\hline FVC, \%pred & $67 \pm 16^{\text {*†‡ }}$ & $66 \pm 16$ & $68 \pm 16$ & $70 \pm 15$ & $70 \pm 14$ & $70 \pm 15$ & $69 \pm 15$ & $69 \pm 16$ & $69 \pm 14$ & $70 \pm 14$ & $70 \pm 14$ & $71 \pm 14$ \\
\hline $\mathrm{FEV}_{1}, \%$ pred & $27 \pm 7^{*}$ & $27 \pm 7$ & $27 \pm 6$ & $28 \pm 6^{*}$ & $28 \pm 6$ & $28 \pm 7$ & $28 \pm 7^{*}$ & $28 \pm 7$ & $28 \pm 6$ & $30 \pm 7$ & $30 \pm 7$ & $30 \pm 7$ \\
\hline TLC, \%pred & $131 \pm 15^{\star \dagger \ddagger}$ & $131 \pm 16$ & $131 \pm 14$ & $127 \pm 14$ & $128 \pm 15$ & $127 \pm 13$ & $127 \pm 15$ & $126 \pm 14$ & $128 \pm 15$ & $125 \pm 14$ & $125 \pm 15$ & $124 \pm 13$ \\
\hline RV, \%pred & $226 \pm 46^{\star \dagger \neq}$ & $226 \pm 43$ & $227 \pm 48$ & $215 \pm 43$ & $214 \pm 45$ & $216 \pm 40$ & $215 \pm 47$ & $212 \pm 47$ & $217 \pm 47$ & $207 \pm 41$ & $207 \pm 45$ & $206 \pm 37$ \\
\hline $\mathrm{Pa}_{\mathrm{O}_{2}}, \mathrm{~mm} \mathrm{Hg}$ & $64 \pm 11^{\ddagger}$ & $64 \pm 11$ & $64 \pm 10$ & $66 \pm 11$ & $67 \pm 11$ & $66 \pm 10$ & $64 \pm 10^{\ddagger}$ & $64 \pm 10$ & $64 \pm 10$ & $62 \pm 9^{\ddagger}$ & $61 \pm 8$ & $64 \pm 10$ \\
\hline $\mathrm{Pa}_{\mathrm{CO}_{2}}, \mathrm{~mm} \mathrm{Hg}$ & $43 \pm 6^{\ddagger}$ & $43 \pm 6$ & $43 \pm 6$ & $42 \pm 5$ & $42 \pm 5$ & $42 \pm 5$ & $43 \pm 6^{\ddagger}$ & $43 \pm 6$ & $43 \pm 6$ & $44 \pm 5^{\ddagger}$ & $44 \pm 5$ & $44 \pm 5$ \\
\hline $\mathrm{DL}_{\mathrm{CO}}, \%$ pred & $26 \pm 8^{\star \dagger \ddagger}$ & $26 \pm 9$ & $25 \pm 8$ & $28 \pm 9^{* \dagger}$ & $29 \pm 9$ & $28 \pm 8$ & $31 \pm 9^{*}$ & $30 \pm 9$ & $31 \pm 10$ & $33 \pm 10$ & $32 \pm 10$ & $35 \pm 10$ \\
\hline 6MWD, m & $366 \pm 87^{\dagger \ddagger}$ & $374 \pm 88$ & $357 \pm 85$ & $385 \pm 96^{* \dagger \S}$ & $383 \pm 97$ & $387 \pm 95$ & $379 \pm 93$ & $376 \pm 92$ & $382 \pm 94$ & $353 \pm 96$ & $347 \pm 88$ & $358 \pm 104$ \\
\hline$\dot{\mathrm{V}}_{\mathrm{E}} / \dot{\mathrm{V}}_{\mathrm{CO}}$ & $46.0 \pm 12.8^{\star \star \ddagger}$ & $47.5 \pm 13.3$ & $44.2 \pm 12.0$ & $43.5 \pm 10.9^{*^{\dagger}}$ & $43.1 \pm 12.0$ & $44.0 \pm 9.6$ & $41.4 \pm 8.5^{*}$ & $40.9 \pm 8.1$ & $41.9 \pm 8.7$ & $38.8 \pm 8.1$ & $37.1 \pm 8.3^{\|}$ & $40.5 \pm 7.7$ \\
\hline SGRQ & $55 \pm 12^{\dagger \neq}$ & $55 \pm 12$ & $56 \pm 12$ & $51 \pm 13$ & $50 \pm 13$ & $53 \pm 13$ & $52 \pm 13$ & $53 \pm 13$ & $52 \pm 12$ & $54 \pm 13$ & $52 \pm 11$ & $55 \pm 14$ \\
\hline UL, \% & 61.5 & 60.8 & 62.4 & 65.0 & 65.7 & 64.1 & 67.8 & 63.6 & 71.2 & 69.0 & 65.5 & 72.7 \\
\hline Low Ex, \% & $61.0^{* \dagger \neq}$ & 66.0 & 55.3 & 39.9 & 41.6 & 38.0 & 34.8 & 30.7 & 38.1 & 31.9 & 32.8 & 30.9 \\
\hline ULLE, \% & $39.6^{* \dagger \neq}$ & 43.3 & 35.3 & 26.6 & 26.1 & 27.2 & 22.8 & 17.6 & $27.0^{\|}$ & 22.1 & 20.7 & 23.6 \\
\hline $\mathrm{BMI}, \mathrm{kg} / \mathrm{m}^{2}$ & $19.4 \pm 1.2^{\star \dagger \ddagger}$ & $19.4 \pm 1.3$ & $19.3 \pm 1.2$ & $23.2 \pm 1.1^{* \dagger}$ & $23.2 \pm 1.2$ & $23.2 \pm 1.1$ & $27.2 \pm 1.4^{*}$ & $27.2 \pm 1.4$ & $27.0 \pm 1.4$ & $30.9 \pm 0.7$ & $31.1 \pm 0.8$ & $30.8 \pm 0.6$ \\
\hline
\end{tabular}

Definition of abbreviations: \%pred $=$ percentage of predicted value; $6 \mathrm{MWD}=6$-minute walk distance; $\mathrm{BMI}=$ body mass index; $\mathrm{DL}$ co $=$ diffusing capacity of carbon

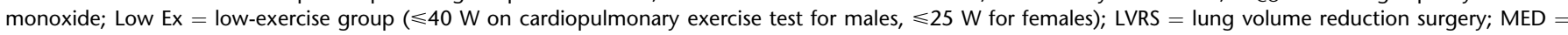

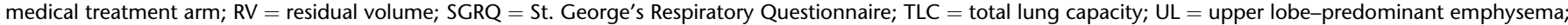
$\mathrm{ULLE}=$ upper lobe-predominant emphysema and low-exercise subgroup; $\dot{\mathrm{V}}_{\mathrm{E}} / \dot{\mathrm{V}}_{\mathrm{CO}}=$ ventilatory efficiency.

* $P<0.05$ compared with obese.

${ }^{+} p<0.05$ compared with overweight.

${ }^{\ddagger} p<0.05$ compared with normal weight.

$\S p<0.05$ compared with underweight.

$\| P<0.05$ LVRS versus MED within BMI stratum. 
predicted $\mathrm{FEV}_{1}$ compared with the other three BMI groups $(27 \pm 7$ vs. $28 \pm 6,28 \pm 7$, and $30 \pm 7 \%$ predicted in the normal weight, overweight, and obese groups, respectively; all $P<0.05)$ as well as a lower percent predicted FVC $(67 \pm 16$ vs. $70 \pm 15$, $69 \pm 15,70 \pm 14 \%$ predicted, respectively; all $P<0.05)$, a higher percent predicted TLC $(131 \pm 15$ vs. $127 \pm 14,127 \pm 15,125 \pm$ $14 \%$ predicted, respectively; all $P<0.05$ ), a higher percent predicted RV (226 \pm 46 vs. $215 \pm 43,215 \pm 47,207 \pm 41 \%$ predicted, respectively; all $P<0.05)$, and a lower percent predicted DLCO $_{\text {CO }}(26 \pm 8$ vs. $28 \pm 9,31 \pm 9,33 \pm 10 \%$ predicted, respectively; all $P<0.05)$. The underweight group also had higher SGRQ scores compared with the other BMI groups $(55 \pm 12$ vs. $51 \pm 13,52 \pm 13,54 \pm 13$, respectively; all $P<0.05$ ), higher $\dot{\mathrm{V}} \mathrm{E} / \dot{\mathrm{V}}_{\mathrm{CO}_{2}}$ during unloaded pedaling $(46.0 \pm 12.8$ vs. $43.5 \pm 10.9$, $41.4 \pm 8.5,38.8 \pm 8.1$, respectively; all $P<0.05)$, and a greater percentage of patients categorized as low exercise capacity $(\leqslant 40$ $\mathrm{W}$ for men and $\leqslant 25 \mathrm{~W}$ for women on incremental cardiopulmonary exercise testing; 61.0 vs. $39.9,34.8,31.9 \%$; all $P<0.05)$. All groups had comparable percentages of patients with upper lobepredominant emphysema on CT scan. Overall, the underweight group had a higher percentage of the upper lobe-predominant emphysema/low-exercise capacity subgroup, as defined by NETT (10) (39.6 vs. 26.6, 22.8, 22.1\%, respectively; all $P<0.05$ ).

Changes in BMI in each BMI group are listed in Table 2 and displayed in Figure 1. BMI remained relatively stable in all weight groups in medically treated patients. \% $\Delta \mathrm{BMI}$ was significantly higher in the LVRS arm compared with the medical arm in the underweight and normal weight groups at all followup time points. In the overweight group, $\% \Delta B M I$ was significantly higher in the LVRS arm at 12 and 24 months compared with the medical arm. There were no significant differences between LVRS and medical arms in the obese group. The differences in $\% \Delta B M I$ between LVRS and medical arms were greatest in the underweight group compared with other BMI groups, and the mean BMI change from baseline progressively increased in the underweight group at 12, 24, and 36 months. The underweight and normal weight groups had a significantly higher percentage of patients in the LVRS arm who had a significant increase in $\mathrm{BMI}(\Delta \mathrm{BMI} \geqslant 5 \%)$ at 6 months compared with the medical arm (see Figure 2).

Table 3 and Figure 3 summarize the changes in physiological parameters, gas exchange, walk distance, health-related quality of life, and ventilator efficiency in patients who had a significant increase in BMI $(\Delta \mathrm{BMI} \geqslant 5 \%)$ and those who did not $(\Delta \mathrm{BMI}<$ $5 \%)$ at 6 months, stratified by treatment. Overall, $24.7 \%$ of the
LVRS group had a $\Delta \mathrm{BMI}$ of at least $5 \%$, whereas only $10.3 \%$ of the MED group had a $\triangle \mathrm{BMI}$ of at least $5 \%$. Compared with the LVRS $\Delta$ BMI $<5 \%$ group, the LVRS $\Delta \mathrm{BMI} \geqslant 5 \%$ group had greater improvements in percent predicted $\mathrm{FEV}_{1}(11.53 \pm 9.31$ vs. $6.58 \pm 8.68 \% ; P<0.0001)$, FVC $(17.51 \pm 15.20$ vs. $7.55 \pm$ $14.88 \% ; P<0.0001)$, and RV $(-66.20 \pm 40.26$ vs. $-47.06 \pm$ $39.87 \% ; P<0.0001)$. Similarly, the LVRS $\Delta \mathrm{BMI} \geqslant 5 \%$ group compared with the LVRS $\triangle \mathrm{BMI}<5 \%$ group had greater improvements in 6-minute walk distance (38.70 \pm 69.57 vs. $7.57 \pm 73.37 \mathrm{~m} ; P<0.0001), \mathrm{Pa}_{\mathrm{CO}_{2}}(-2.80 \pm 5.02$ vs. $-1.70 \pm$ $4.66 \mathrm{~mm} \mathrm{Hg} ; P=0.0300), \mathrm{Pa}_{\mathrm{O}_{2}}(7.48 \pm 9.18$ vs. $3.73 \pm 9.41 \mathrm{~mm}$ $\mathrm{Hg} ; P<0.0002)$, and SGRQ scores $(-15.30 \pm 14.08$ vs. $-9.15 \pm$ 14.44; $P<0.0001)$. Changes in maximal expiratory pressures $(12.73 \pm 49.08$ vs. $3.54 \pm 32.22 ; P=0.0205)$ were greater in the LVRS $\Delta \mathrm{BMI} \geqslant 5 \%$ group compared with the LVRS $\Delta \mathrm{BMI}<$ $5 \%$ group. $\dot{\mathrm{VE}} / \dot{\mathrm{V}}_{\mathrm{CO}_{2}}$ decreased at 6 months in the LVRS $\Delta \mathrm{BMI} \geqslant$ $5 \%$ group, whereas in the LVRS $\Delta \mathrm{BMI}<5 \%$ group the $\dot{\mathrm{VE}} / \dot{\mathrm{V}}_{\mathrm{CO}_{2}}$ increased $(-1.58 \pm 6.20$ vs. $0.22 \pm 8.20 ; P=0.0306)$. There were no significant differences in changes from baseline in the aforementioned parameters in the MED $\triangle \mathrm{BMI} \geqslant 5 \%$ group compared with the MED $\triangle \mathrm{BMI}<5 \%$ group, with the exception of 6-minute walk distance, which decreased more in the MED $\Delta \mathrm{BMI} \geqslant 5 \%$ group and in the MED $\Delta \mathrm{BMI}<5 \%$ group $(-46.98 \pm 8.18$ vs. $-21.34 \pm 2.78 ; P=0.0032)$.

In multivariate analysis using a binary logistic regression model of $\triangle \mathrm{BMI}$ equal to or greater than $5 \%$ on treatment arm (LVRS vs. medical), sex, exercise category (low- vs. highexercise capacity), upper lobe predominance (vs. other), baseline lung function, baseline $\dot{\mathrm{V}}_{\mathrm{E}} / \dot{\mathrm{V}}_{\mathrm{CO}_{2}}$, and BMI group, the LVRS arm (vs. MED) and the underweight group (vs. normal) were significantly associated with a $\triangle \mathrm{BMI}$ equal to or greater than $5 \%$ (odds ratio [OR], 2.70; 95\% confidence interval [CI], 1.814.04; and OR, 2.36; 95\% CI, 1.39-4.01, respectively). Baseline FVC was inversely associated with $\triangle \mathrm{BMI}$ equal to or greater than 5\% (OR, 0.97; 95\% CI, 0.95-0.99). Sex and baseline exercise category, $\mathrm{FEV}$, TLC, RV, and $\dot{\mathrm{V}} / \mathrm{V}_{\mathrm{CO}_{2}}$ were not significantly associated with $\triangle \mathrm{BMI}$ equal to or greater than $5 \%$ (see Table 4).

\section{DISCUSSION}

We showed in a large group of well-characterized patients with advanced emphysema that LVRS was more likely to be associated with significant weight gain, whereas medical therapy alone had little effect on weight. Using preoperative BMI, we were also

TABLE 2. PERCENT CHANGE IN BODY MASS INDEX (BMI) OVER TIME WITHIN BASELINE BMI GROUP

\begin{tabular}{|c|c|c|c|c|c|c|c|c|c|c|c|c|}
\hline & \multicolumn{3}{|c|}{ Underweight (BMI < 21) } & \multicolumn{3}{|c|}{ Normal Weight (BMI 21-25) } & \multicolumn{3}{|c|}{ Overweight (BMI 25-30) } & \multicolumn{3}{|c|}{ Obese $(\mathrm{BMI}>30)$} \\
\hline & $\begin{array}{c}\text { LVRS } \\
(n=97)\end{array}$ & $\begin{array}{c}\text { MED } \\
(n=85)\end{array}$ & $P$ Value & $\begin{array}{c}\text { LVRS } \\
(n=207)\end{array}$ & $\begin{array}{c}\text { MED } \\
(n=184)\end{array}$ & $P$ Value & $\begin{array}{c}\text { LVRS } \\
(n=176)\end{array}$ & $\begin{array}{c}\text { MED } \\
(n=215)\end{array}$ & $P$ Value & $\begin{array}{c}\text { LVRS } \\
(n=58)\end{array}$ & $\begin{array}{c}\text { MED } \\
(n=55)\end{array}$ & $P$ Value \\
\hline $6 \mathrm{mo}$ & $\begin{array}{c}4.13 \pm 8.65 \\
(n=79)\end{array}$ & $\begin{array}{c}0.89 \pm 4.82 \\
(n=51)\end{array}$ & 0.0164 & $\begin{array}{c}1.67 \pm 6.02 \\
(n=169)\end{array}$ & $\begin{array}{c}-0.42 \pm 3.79 \\
(n=140)\end{array}$ & 0.0004 & $\begin{array}{c}-0.20 \pm 6.34 \\
(n=150)\end{array}$ & $\begin{array}{c}-0.14 \pm 4.38 \\
(n=160)\end{array}$ & 0.9276 & $\begin{array}{c}0.25 \pm 6.30 \\
(n=45)\end{array}$ & $\begin{array}{c}2.23 \pm 3.62 \\
(n=44)\end{array}$ & 0.0735 \\
\hline $12 \mathrm{mo}$ & $\begin{array}{c}6.70 \pm 9.76 \\
(n=70)\end{array}$ & $\begin{array}{c}2.25 \pm 6.02 \\
(n=44)\end{array}$ & 0.0077 & $\begin{array}{c}3.30 \pm 7.69 \\
(n=141)\end{array}$ & $\begin{array}{c}-0.45 \pm 5.61 \\
(n=115)\end{array}$ & $<0.0001$ & $\begin{array}{l}2.37 \pm 8.07 \\
(n=131)\end{array}$ & $\begin{array}{c}-0.19 \pm 5.77 \\
(n=136)\end{array}$ & 0.0029 & $\begin{array}{c}2.72 \pm 6.87 \\
(n=41)\end{array}$ & $\begin{array}{c}1.47 \pm 5.49 \\
(n=34)\end{array}$ & 0.3915 \\
\hline $24 \mathrm{mo}$ & $\begin{array}{c}8.25 \pm 11.62 \\
(n=60)\end{array}$ & $\begin{array}{c}1.21 \pm 7.60 \\
(n=25)\end{array}$ & 0.0066 & $\begin{array}{c}4.07 \pm 7.84 \\
(n=121)\end{array}$ & $\begin{array}{l}0.58 \pm 7.59 \\
(\mathrm{n}=95)\end{array}$ & 0.0012 & $\begin{array}{l}3.32 \pm 8.52 \\
(n=110)\end{array}$ & $\begin{array}{c}-0.45 \pm 6.89 \\
(n=116)\end{array}$ & 0.0003 & $\begin{array}{c}4.69 \pm 8.08 \\
(n=35)\end{array}$ & $\begin{array}{c}1.25 \pm 6.33 \\
(n=28)\end{array}$ & 0.0695 \\
\hline $36 \mathrm{mo}$ & $\begin{array}{c}9.05 \pm 12.14 \\
(n=32)\end{array}$ & $\begin{array}{c}0.85 \pm 7.64 \\
(n=16)\end{array}$ & 0.0117 & $\begin{array}{c}3.28 \pm 8.67 \\
(n=77)\end{array}$ & $\begin{array}{l}-0.32 \pm 8.44 \\
(n=55)\end{array}$ & 0.0188 & $\begin{array}{l}3.43 \pm 9.10 \\
(n=67)\end{array}$ & $\begin{array}{l}0.97 \pm 6.95 \\
(n=64)\end{array}$ & 0.0859 & $\begin{array}{c}3.48 \pm 9.65 \\
(n=25)\end{array}$ & $\begin{array}{c}2.46 \pm 7.44 \\
(n=14)\end{array}$ & 0.7352 \\
\hline $\begin{array}{l}\% \text { of each group } \\
\text { with } \Delta \mathrm{BMI} \geqslant 5 \% \\
\text { at } 6 \mathrm{mo}\end{array}$ & 37.97 & 17.65 & 0.0182 & 23.67 & 3.57 & $<0.0001$ & 18.00 & 11.88 & 0.1510 & 22.22 & 18.18 & 0.7928 \\
\hline
\end{tabular}

Definition of abbreviations: BMI = body mass index; LVRS = lung volume reduction surgery; MED = medical treatment arm.

All data are expressed as means \pm SD, except percentage of each group with $\triangle B$ MI equal to or greater than $5 \%$ at 6 months. $P$ values are for differences between LVRS and MED within the BMI group.

Bold indicates $P$ values less than 0.05 , the level of statistical significance. 
A
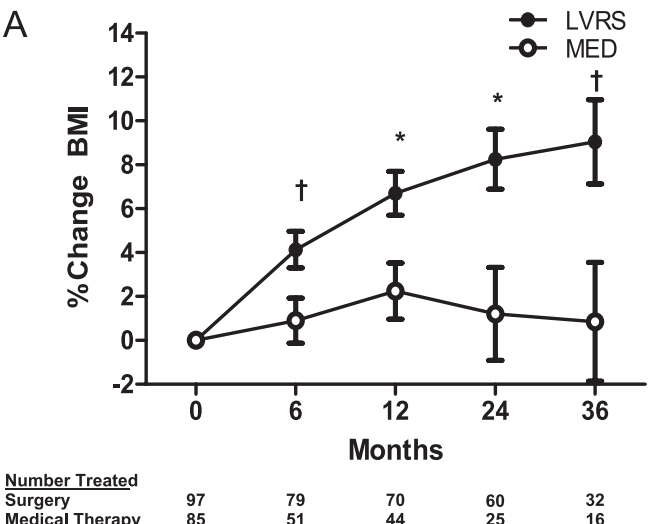

C

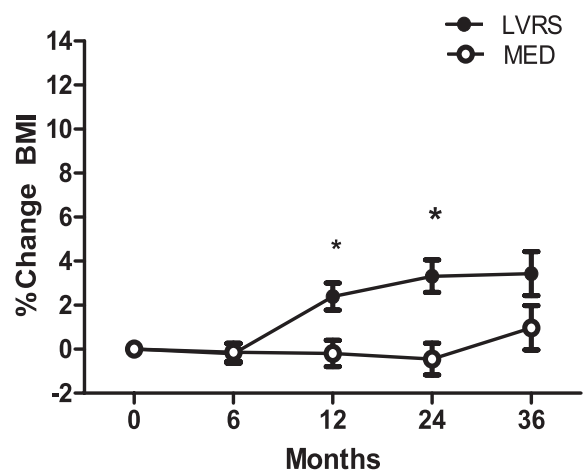

Number Treated

Surgery
Medical Therapy

176
215 $\begin{array}{llll}150 & 131 & 110 & 67 \\ 160 & 136 & 116 & 64\end{array}$
B

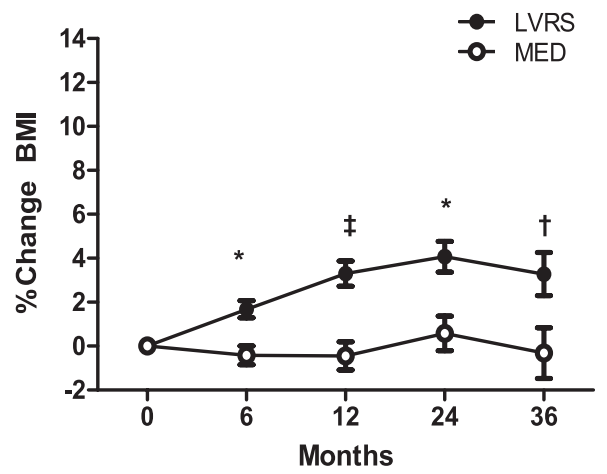
Surgery

rapy

$207 \quad 169$

169
140

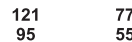

D

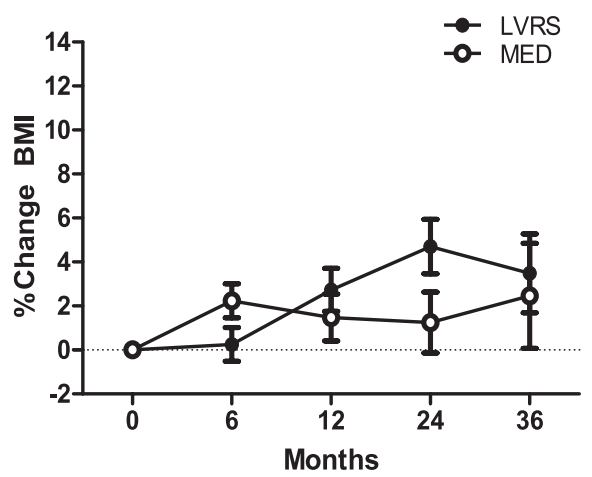

Number Treated Medical Therapy

$\begin{array}{lllll}58 & 45 & 41 & 35 & 25 \\ 55 & 44 & 34 & 28 & 14\end{array}$
Figure 1. Percent change in body mass index by treatment group and body mass index (BMI) group: $(A)$ underweight, (B) normal weight, $(C)$ overweight, and $(D)$ obese. Solid circles represent patients in the lung volume reduction surgery (LVRS) group, and open circles represent patients in the medical therapy (MED) group. Data present means \pm SE. ${ }^{*} p<0.01,{ }^{\dagger} p<0.05,{ }^{\ddagger} p<$ 0.0001 for LVRS versus MED. able to identify patient groups more likely to gain weight, as well as their associated changes in lung function and ventilatory efficiency. Significant weight gain was accomplished in those who were not obese at baseline, and these effects were independent of preoperative exercise subgroup and distribution of emphysema on CT scan, which were primary predictors of outcome in the NETT. The changes in BMI were most profound in the underweight group, followed by the normal weight and overweight groups. In addition, the underweight group continued to gain weight through 36 months of follow-up, whereas the normal weight and overweight groups achieved a plateau of weight gain at 24 months. In the LVRS arm, those who experienced significant weight gain had greater improvements in spirometry, respiratory muscle strength, lung volumes, ventilatory efficiency, healthrelated quality of life, and 6-minute walk distance compared with those without a significant weight gain. Therefore, we posit that these changes in lung physiology exert a positive effect on BMI by improving exercise capacity, with a resultant increase in muscle mass and a reduction of resting energy expenditure (REE).

What defines a significant weight change is a matter of debate. In the elderly population, involuntary weight loss of $5 \%$ in 6 months is associated with increased mortality (14), and intentional weight loss of $5 \%$ in the obese population significantly reduces cardiovascular risk (15). However, in the underweight population, it is unclear how much weight gain is necessary to have a significant impact on outcome. A prospective study of an aggressive nutritional support program in 203 patients with COPD has shown that a weight gain of $2 \mathrm{~kg}$ over 8 weeks in nutritionally depleted patients was associated with improvement in long-term outcomes (7). In addition, a small study of 30 LVRS patients revealed that a $5 \%$ increase in BMI was associated with improved health-related quality of life, dyspnea scores, and lung function (17). On the basis of these data, we chose a threshold of a 5\% increase in BMI in 6 months to be considered clinically significant for our analysis.

Cachexia is a common systemic manifestation of COPD, affecting $20-35 \%$ of patients $(18,19)$. The underlying mechanisms are unclear, but multiple factors have been implicated, including increased $\operatorname{REE}(4,20)$, elevated systemic inflammation (5), derangement of anabolic hormone metabolism $(21,22)$, and muscle disuse atrophy. Sergi and colleagues found that REE was $10 \%$ higher in patients with COPD than in normal subjects

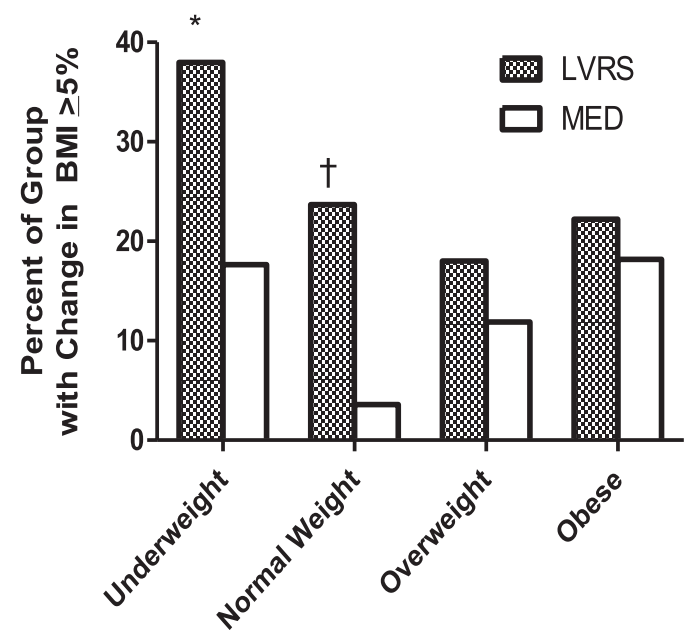

Figure 2. Percentage of each body mass index (BMI) group with an increase in $\mathrm{BMI}$ of at least $5 \%$ at 6 months after randomization to lung volume reduction surgery (LVRS) or medical therapy (MED). ${ }^{*} P<0.05$, ${ }^{\dagger} p<0.0001$ for LVRS versus MED. 
TABLE 3. CHANGES IN LUNG FUNCTION, RESPIRATORY MUSCLE STRENGTH, 6-MINUTE WALK DISTANCE, RESTING GAS EXCHANGE, HEALTH-RELATED QUALITY OF LIFE, AND VENTILATORY EFFICIENCY STRATIFIED BY TREATMENT GROUP AND CHANGE IN BODY MASS INDEX AT 6 MONTHS IN 900 PATIENTS SURVIVING AT 6 MONTHS

\begin{tabular}{|c|c|c|c|c|c|c|}
\hline \multirow[b]{2}{*}{ Variable } & \multicolumn{3}{|c|}{ LVRS } & \multicolumn{3}{|c|}{ MED } \\
\hline & $\Delta \mathrm{BMI} \geqslant 5 \%(n=117)$ & $\Delta \mathrm{BMI}<5 \%(n=357)$ & $P$ Value & $\Delta \mathrm{BMI} \geqslant 5 \%(n=44)$ & $\Delta \mathrm{BMI}<5 \%(n=382)$ & $P$ Value \\
\hline $\mathrm{FEV}_{1}, \%$ pred & $11.53 \pm 9.31$ & $6.58 \pm 8.68$ & $<0.0001$ & $-0.59 \pm 4.63$ & $-0.38 \pm 4.27$ & 0.7622 \\
\hline FVC, \%pred & $17.51 \pm 15.20$ & $7.55 \pm 14.88$ & $<0.0001$ & $-2.05 \pm 9.21$ & $-1.44 \pm 10.09$ & 0.6091 \\
\hline RV, \%pred & $-66.20 \pm 40.26$ & $-47.06 \pm 39.87$ & $<0.0001$ & $-4.82 \pm 36.93$ & $1.78 \pm 29.63$ & 0.1740 \\
\hline TLC, \%pred & $-16.30 \pm 11.84$ & $-14.46 \pm 13.17$ & 0.1797 & $-2.11 \pm 10.31$ & $-0.29 \pm 10.23$ & 0.2640 \\
\hline DLco, \%pred & $4.10 \pm 9.10$ & $1.44 \pm 8.34$ & 0.0100 & $-1.23 \pm 5.80$ & $-2.01 \pm 6.68$ & 0.5108 \\
\hline MIP, \%pred & $25.20 \pm 38.34$ & $18.43 \pm 33.93$ & 0.0706 & $6.62 \pm 23.48$ & $0.80 \pm 31.26$ & 0.2326 \\
\hline MEP, \%pred & $12.73 \pm 49.08$ & $3.54 \pm 32.22$ & 0.0205 & $9.56 \pm 37.41$ & $0.87 \pm 30.32$ & 0.0834 \\
\hline $6 \mathrm{MWD}, \mathrm{m}$ & $38.70 \pm 69.57$ & $7.57 \pm 73.37$ & $<0.0001$ & $-46.98 \pm 8.18$ & $-21.34 \pm 2.78$ & 0.0032 \\
\hline $\mathrm{Pa}_{\mathrm{CO}_{2}}, \mathrm{~mm} \mathrm{Hg}$ & $-2.80 \pm 5.02$ & $-1.70 \pm 4.66$ & 0.0300 & $1.11 \pm 3.21$ & $0.65 \pm 3.69$ & 0.4245 \\
\hline $\mathrm{Pa}_{\mathrm{O}_{2}}, \mathrm{~mm} \mathrm{Hg}$ & $7.48 \pm 9.18$ & $3.73 \pm 9.41$ & 0.0002 & $-1.68 \pm 8.83$ & $1.22 \pm 6.98$ & 0.6864 \\
\hline SGRQ & $-15.30 \pm 14.08$ & $-9.15 \pm 14.44$ & $<0.0001$ & $2.83 \pm 8.13$ & $1.92 \pm 10.49$ & 0.5806 \\
\hline$\dot{\mathrm{V}}_{\mathrm{E}} / \dot{\mathrm{V}}_{\mathrm{CO}}$ & $-1.58 \pm 6.20$ & $0.22 \pm 8.20$ & 0.0306 & $-1.73 \pm 5.05$ & $0.03 \pm 8.02$ & 0.1610 \\
\hline
\end{tabular}

Definition of abbreviations: $6 \mathrm{MWD}=6$-minute walk distance; $\mathrm{BMI}=$ body mass index; DLCO diffusing capacity of carbon monoxide; LVRS $=$ lung volume reduction surgery; MED = medical treatment arm; MEP = maximal expiratory pressure; MIP = maximal inspiratory pressure; RV = residual volume; SGRQ $=$ St. George's Respiratory Questionnaire; TLC $=$ total lung capacity; $\dot{\mathrm{V}} / \dot{\mathrm{V}}_{\mathrm{CO}} \mathrm{O}_{2}=$ ventilatory efficiency.

All values are expressed as means $\pm \mathrm{SD}$. All data were reported at 6 months of follow-up, except for $\mathrm{DL}_{\mathrm{CO}}$, which was determined at 12 months

Bold indicates $P$ values less than 0.05 , the level of statistical significance.

similar in age, height, and weight (20). Similarly, Schols and colleagues found that REE, when adjusted for fat-free mass, was higher in patients with COPD who lost weight compared with those whose weight remained stable (23). Serum levels of TNF- $\alpha$ are higher in cachectic patients with COPD compared with noncachectic patients with COPD and healthy control subjects $(24,25)$, and elevations in IL-1 and IL-6 may also play a role in the development of cachexia $(26,27)$. Reductions in circulating levels of testosterone, growth hormone, insulin-like growth factor, and leptin have also been found in cachectic patients with COPD $(21,22,25)$.

LVRS has numerous beneficial effects on metabolism and systemic inflammation, and can potentially reduce the processes leading to cachexia in COPD. In a study of 30 LVRS and 22 pulmonary rehabilitation patients, the LVRS group had an $8 \%$ decrease in REE adjusted for fat-free mass, compared with the rehabilitation group, which had in increase of $4.2 \%$ (17). There was also a profound decrease in respiratory muscle oxygen consumption by $44.1 \%$, which correlated well with decreases in RV after surgery. Another study of 28 LVRS patients found significant reductions in serum levels of TNF- $\alpha$, IL-6, and IL- 8 after surgery, which again correlated with reductions in RV (11). Similarly, in 33 LVRS patients, the reduction in RV correlated with increases in serum ghrelin (an appetite-stimulating hormone), decreases in serum leptin (a fat-burning hormone and appetite suppressant), and increases in fat-free mass (6). In addition, all these studies demonstrated weight gain after LVRS. One study found that the reduction in RV after LVRS not only correlated with increases in BMI but was also related to improved pulmonary and cardiovascular outcomes (28). Therefore, it seems that the reduction in hyperinflation from lung volume reduction is a major mechanism responsible for the reduction in energy expenditure, systemic inflammation, and anabolic hormone metabolism, and weight gain seen after LVRS.

However, these studies involved small numbers of patients with primarily low baseline BMI (mean BMI approximately 22 to 23 $\mathrm{kg} / \mathrm{m}^{2}$ across studies). As in prior studies, our study shows that reduction in residual volume was greater in those with significant weight gain, supporting the notion that the reduction in air trapping leads to decreased systemic inflammation and reduced REE. Unlike other studies, our study involved the analysis of 1,077 patients with a wide range of BMI, and is the first to stratify changes in weight according to baseline BMI. We also found weight gain in those who were normal weight and overweight, but not in those who were obese. The greatest increases in BMI occurred in the underweight group, suggesting that REE and systemic inflammation are highest in this group, which was more profoundly affected by LVRS.

An important contribution of our study is the demonstration of improvements in ventilatory efficiency and respiratory muscle strength in those who had significant weight gain. Ventilatory efficiency, defined as the ratio of minute ventilation to carbon dioxide production (16), has been shown to have prognostic value in heart failure and several pulmonary diseases $(29,30)$. At rest or during mild exercise, $\dot{\mathrm{V}} / \mathrm{V}_{\mathrm{CO}_{2}}$ can vary widely depending on $\mathrm{Pa}_{\mathrm{CO}_{2}}$, anxiety, breathing pattern, ventilation-perfusion

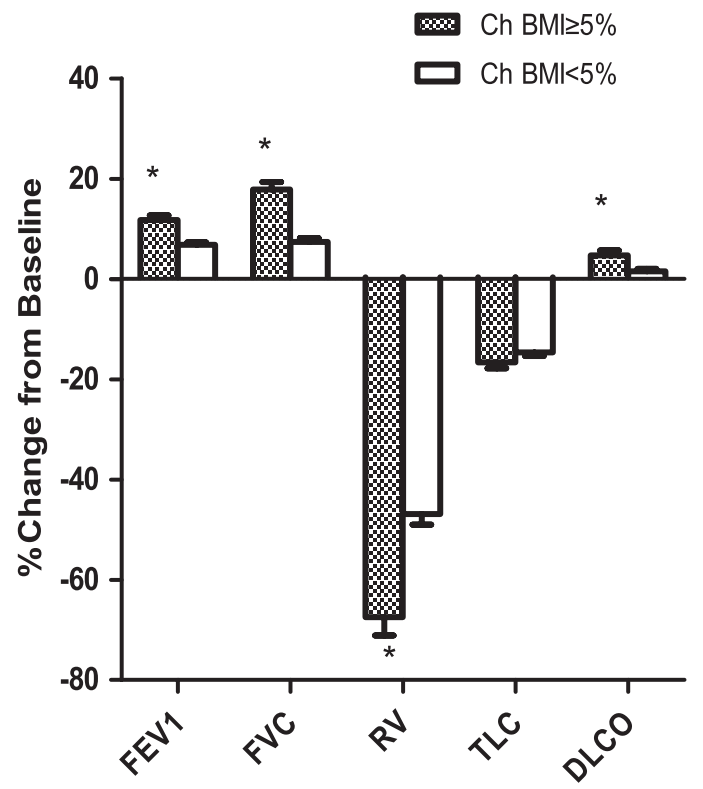

Figure 3. Change in body mass index (BMI) at 6 months and percent changes in lung function measures from baseline to 6 months (except the diffusing capacity of carbon monoxide [ $\mathrm{D} \mathrm{L}_{\mathrm{co}}$ ], which was assessed at $12 \mathrm{mo}$ ). Shaded columns represent patients who had an increase in BMI of at least $5 \%$ at 6 months, and open columns represent patients with a change in BMI less than $5 \%$. Data represent the lung volume reduction surgery (LVRS) treatment group and are expressed as means \pm SE. ${ }^{*} P<$ 0.0001 for $\Delta \mathrm{BMI} \geqslant 5 \%$ versus $\Delta \mathrm{BMI}<5 \%$. 
TABLE 4. ADJUSTED ODDS RATIOS IN MULTIVARIATE ANALYSIS FOR CHANGE IN BODY MASS INDEX OF AT LEAST 5\% AT 6 MONTHS IN 837 NON-HIGH-RISK PATIENTS SURVIVING TO 6 MONTHS

\begin{tabular}{|c|c|c|c|c|}
\hline Variable & OR & $95 \% \mathrm{Cl}$ & $P$ Value & $\begin{array}{l}P \text { Value for } \\
\text { Combination } \\
\text { of Factors }\end{array}$ \\
\hline LVRS vs. MED & 2.70 & $1.81,4.04$ & $<0.0001$ & \\
\hline Female vs. male & 0.79 & $0.50,1.25$ & 0.2998 & \\
\hline Low exercise vs. high exercise & 0.93 & $0.61,1.41$ & 0.7194 & \\
\hline UL predominant vs. other & 1.48 & $0.98,2.25$ & 0.0651 & \\
\hline Underweight vs. normal & 2.36 & $1.39,4.01$ & 0.0015 & 0.0057 \\
\hline Overweight vs. normal & 1.02 & $0.64,1.62$ & 0.9301 & \\
\hline Obese vs. normal & 1.52 & $0.80,2.90$ & 0.2015 & \\
\hline Baseline FVC, \% predicted & 0.97 & $0.95,0.99$ & 0.0019 & \\
\hline Baseline $\mathrm{FEV}_{1}, \%$ predicted & 1.03 & $0.99,1.07$ & 0.2174 & \\
\hline Baseline TLC, \% predicted & 1.02 & $0.99,1.05$ & 0.1522 & \\
\hline Baseline RV, \% predicted & 1.00 & $0.99,1.01$ & 0.7202 & \\
\hline Baseline $\dot{\mathrm{V}} \mathrm{E} / \dot{\mathrm{V}}_{\mathrm{CO}}$ & 1.00 & $0.98,1.01$ & 0.6479 & \\
\hline
\end{tabular}

Definition of abbreviations: $\mathrm{Cl}=$ confidence interval; LVRS = lung volume reduction surgery; $\mathrm{MED}=$ medical treatment arm; $\mathrm{OR}=$ odds ratio; $\mathrm{RV}=$ residual volume; $\mathrm{TLC}=$ total lung capacity; $\mathrm{UL}=$ upper lobe; $\dot{\mathrm{V}} \mathrm{E} / \dot{\mathrm{V}}_{\mathrm{CO}} 2=$ ventilatory efficiency.

Bold indicates $P$ values less than 0.05 , the level of statistical significance.

matching, underlying metabolic demand, and ratio of dead space to tidal volume $\left(\mathrm{VD}_{\mathrm{D}} / \mathrm{V}_{\mathrm{T}}\right)$ (31). The observed reductions of $\dot{\mathrm{V}}_{\mathrm{E}} /$ $\dot{\mathrm{V}}_{2}$ after LVRS may be due to decreases in $\mathrm{VD} / \mathrm{VT}$, alterations in breathing pattern, and a fall in resting $\mathrm{Pa}_{\mathrm{CO}_{2}}$ (32). These improvements in ventilatory efficiency may explain the decreases in REE, thereby leading to a gain in weight for a given caloric input.

Although this is the largest analysis of changes in BMI after LVRS, some limitations should be acknowledged. This study involved a select group of patients with advanced emphysema, with a post-hoc breakdown of patients into groups based on their BMI at baseline. In addition, incomplete follow-up is a weakness of our data set. Two hundred and forty (22\%) of the 1,077 patients in our study population did not have data at 6 months, either due to death in the first 6 months of follow-up (53 patients) or because they did not return for the 6-month visit (187 patients), possibly due to declining health or for some reason unrelated to health. An analysis assuming that all those who missed the 6 -month visit (due to death or other reason) were in the $\Delta \mathrm{BMI}$ $<5 \%$ group gave results consistent with our primary results. An analysis assuming those who died before 6 months were in the $\Delta \mathrm{BMI}<5 \%$ group and that those who missed the visit for other reasons were in the $\Delta \mathrm{BMI} \geqslant 5 \%$ group gave results that were partially consistent with the primary results; in this analysis, LVRS and medical patients had similar odds of weight gain. Although our assumptions were extreme given the unequal proportions in the LVRS and medical groups of patients with $\Delta \mathrm{BMI}$ equal to or greater than $5 \%$, it is possible that loss to follow-up affected our findings.

Another limitation is that because only BMI was measured, it is not clear that the observed weight gain is due to cachexia reversal in these patients. Indeed, weight gain was seen in those who were normal weight or overweight, two groups that are less likely to have muscle cachexia. However, the significant improvements in maximal inspiratory and expiratory pressures are consistent with the concept that the observed weight gain is due to an increase in muscle mass. The small size of the obese group and the exclusion of patients with BMI greater than $31.1 \mathrm{~kg} / \mathrm{m}^{2}$ (males) or 32.3 $\mathrm{kg} / \mathrm{m}^{2}$ (females) also limit our ability to make firmer conclusions about obese patients with respect to their changes in BMI over time. The NETT protocol did not include measures of inflammatory cytokines or hormones, or nutritional evaluation such as anthropometric and metabolic parameters, to validate the results from prior studies. Last, events after randomization such as exacerbations, hospitalizations, and complications that could have had an effect on weight change were not accounted for in our analysis.

Nevertheless, our study imparts a significant contribution to our current understanding of the beneficial effects of LVRS. Our findings of weight gain after LVRS validate the findings in previous smaller studies in a large cohort of well-characterized patients in a randomized controlled trial and provide greater understanding of the patient profiles that gain weight after LVRS. We showed that weight gain is associated with changes in spirometry, respiratory muscle strength, lung volumes and ventilatory efficiency after LVRS. These physiological changes may be at least partially responsible for the weight gain in patients who undergo LVRS. In addition, a thorough and rigorous nutritional, hormonal, and metabolic assessment before LVRS may allow better prediction of changes in body composition and weight after surgery.

Author disclosures are available with the text of this article at www.atsjournals.org.

Acknowledgment: The authors thank Arthur Gelb, M.D., Lakewood Regional Medical Center (Lakewood, CA).

Members of the NETT Research Group: Office of the Chair of the Steering Committee, University of Pennsylvania, Philadelphia, PA: Alfred P. Fishman, M.D. (Chair); Betsy Ann Bozzarello; Ameena Al-Amin.

\section{Clinical Centers}

Baylor College of Medicine, Houston, TX: Marcia Katz, M.D. (Principal Investigator); Carolyn Wheeler, R.N., B.S.N. (Principal Clinic Coordinator); Elaine Baker, R.R.T., R.P.F.T.; Peter Barnard, Ph.D., R.P.F.T.; Phil Cagle, M.D.; James Carter, M.D.; Sophia Chatziioannou, M.D.; Karla Conejo-Gonzales; Kimberly Dubose, R.R.T; John Haddad, M.D.; David Hicks, R.R.T., R.P.F.T.; Neal Kleiman, M.D.; Mary MilburnBarnes, C.R.T.T.; Chinh Nguyen, R.P.F.T.; Michael Reardon, M.D.; Joseph ReevesViets, M.D.; Steven Sax, M.D.; Amir Sharafkhaneh, M.D.; Owen Wilson, Ph.D.; Christine Young P.T.; Rafael Espada, M.D. (Principal Investigator, 1996-2002); Rose Butanda (1999-2001); Minnie Ellisor (2002); Pamela Fox, M.D. (1999-2001); Katherine Hale, M.D. (1998-2000); Everett Hood, R.P.F.T. (1998-2000); Amy Jahn (1998-2000); Satish Jhingran, M.D. (1998-2001); Karen King R.P.F.T. (19981999); Charles Miller III, Ph.D. (1996-1999); Imran Nizami, M.D. (Co-Principal Investigator, 2000-2001); Todd Officer (1998-2000); Jeannie Ricketts (19982000); Joe Rodarte, M.D. (Co-Principal Investigator, 1996-2000); Robert Teague, M.D. (Co-Principal Investigator, 1999-2000); Kedren Williams (1998-1999).

Brigham and Women's Hospital, Boston, MA: John Reilly, M.D. (Principal Investigator); David Sugarbaker, M.D. (Co-Principal Investigator); Carol Fanning, R.R.T. (Principal Clinic Coordinator); Simon Body, M.D.; Sabine Duffy, M.D.; Vladmir Formanek, M.D.; Anne Fuhlbrigge, M.D.; Philip Hartigan, M.D.; Sarah Hooper, E.P.; Andetta Hunsaker, M.D.; Francine Jacobson, M.D.; Marilyn Moy, M.D.; Susan Peterson, R.R.T.; Roger Russell, M.D.; Diane Saunders; Scott Swanson, M.D. (Co-Principal Investigator, 1996-2001).

Cedars-Sinai Medical Center, Los Angeles, CA: Rob McKenna, M.D. (Principal Investigator); Zab Mohsenifar, M.D. (Co-Principal Investigator); Carol Geaga, R. N. (Principal Clinic Coordinator); Manmohan Biring, M.D.; Susan Clark, R.N., M. N.; Jennifer Cutler, M.D.; Robert Frantz, M.D.; Peter Julien, M.D.; Michael Lewis, M.D.; Jennifer Minkoff-Rau, MSW; Valentina Yegyan, B.S., C.P.F.T.; Milton Joyner, B.A. (1996-2002).

Cleveland Clinic Foundation, Cleveland, $\mathrm{OH}$ : Malcolm DeCamp, M.D. (Principal Investigator); James Stoller, M.D. (Co-Principal Investigator); Yvonne Meli, R.N.C. (Principal Clinic Coordinator); John Apostolakis, M.D.; Darryl Atwell, M.D.; Jeffrey Chapman, M.D.; Pierre DeVilliers, M.D.; Raed Dweik, M.D.; Erik Kraenzler, M.D.; Rosemary Lann, L.I.S.W.; Nancy Kurokawa, R.R.T., C.P.F.T.; Scott Marlow, R.R.T.; Kevin McCarthy, R.C.P.T.; Priscilla McCreight, R.R.T. C.P.F.T.; Atul Mehta, M.D.; Moulay Meziane, M.D.; Omar Minai, M.D.; Mindi Steiger, R.R.T.; Kenneth White, R.P.F.T.; Janet Maurer, M.D. (Principal Investigator, 1996-2001); Terri Durr, R.N. (2000-2001); Charles Hearn, D.O. (1998-2001); Susan Lubell, P.A.-C. (1999 2000); Peter O'Donovan, M.D. (1998-2003); Robert Schilz, D.O. (1998-2002).

Columbia University, New York, NY in consortium with Long Island Jewish Medica Center, New Hyde Park, NY: Mark Ginsburg, M.D. (Principal Investigator); Byron Thomashow, M.D. (Co-Principal Investigator); Patricia Jellen, M.S.N., R.N. (Principal Clinic Coordinator); John Austin, M.D.; Matthew Bartels, M.D.; Yahya Berkmen M.D.; Patricia Berkoski, M.S., R.R.T. (Site Coordinator, LII); Frances Brogan, M.S. N., R.N.; Amy Chong, B.S., C.R.T.; Glenda DeMercado, B.S.N.; Angela DiMango, M.D.; Sandy Do, M.S., P.T.; Bessie Kachulis, M.D.; Arfa Khan, M.D.; Berend Mets, M.D.; Mitchell O'Shea, B.S., R.T., C.P.F.T.; Gregory Pearson, M.D.; Leonard Rossoff, M.D.; Steven Scharf, M.D., Ph.D. (Co-Principal Investigator, 1998-2002); Maria Shiau, M.D.; Paul Simonelli, M.D.; Kim Stavrolakes, M.S., P.T.; Donna Tsang, B.S.; 
Denise Vilotijevic, M.S., P.T.; Chun Yip, M.D.; Mike Mantinaos, M.D. (1998-2001); Kerri McKeon, B.S., R.R.T., R.N. (1998-1999); Jacqueline Pfeffer, M.P.H., P.T. (1997-2002).

Duke University Medical Center, Durham, NC: Neil Maclntyre, M.D. (Principal Investigator); R. Duane Davis, M.D. (Co-Principal Investigator); John Howe R.N. (Principal Clinic Coordinator); R. Edward Coleman, M.D.; Rebecca Crouch R.P.T.; Dora Greene; Katherine Grichnik, M.D.; David Harpole, Jr., M.D.; Abby Krichman, R.R.T.; Brian Lawlor, R.R.T.; Holman McAdams, M.D.; John Plankeel, M.D.; Susan Rinaldo-Gallo, M.E.D.; Sheila Shearer, R.R.T.; Jeanne Smith, A.C.S.W Mark Stafford-Smith, M.D.; Victor Tapson, M.D.; Mark Steele, M.D. (1998-1999); Jennifer Norten, M.D. (1998-1999).

Mayo Foundation, Rochester, MN: James Utz, M.D. (Principal Investigator); Claude Deschamps, M.D. (Co-Principal Investigator); Kathy Mieras, C.C.R.P. (Principal Clinic Coordinator); Martin Abel, M.D.; Mark Allen, M.D.; Deb Andrist, R.N.; Gregory Aughenbaugh, M.D.; Sharon Bendel, R.N.; Eric Edell, M.D.; Marlene Edgar; Bonnie Edwards; Beth Elliot, M.D.; James Garrett, R.R.T.; Delmar Gillespie M.D.; Judd Gurney, M.D.; Boleyn Hammel; Karen Hanson, R.R.T.; Lori Hanson, R.R.T.; Gordon Harms, M.D.; June Hart; Thomas Hartman, M.D.; Robert Hyatt, M.D. Eric Jensen, M.D.; Nicole Jenson, R.R.T.; Sanjay Kalra, M.D.; Philip Karsell, M.D. Jennifer Lamb; David Midthun, M.D.; Carl Mottram, R.R.T.; Stephen Swensen M.D.; Anne-Marie Sykes, M.D.; Karen Taylor; Norman Torres, M.D.; Rolf Hubmayr, M.D. (1998-2000); Daniel Miller, M.D. (1999-2002); Sara Bartling, R.N. (19982000); Kris Bradt (1998-2002).

National Jewish Medical and Research Center, Denver, CO: Barry Make, M.D. (Principal Investigator); Marvin Pomerantz, M.D. (Co-Principal Investigator); Mary Gilmartin, R.N., R.R.T. (Principal Clinic Coordinator); Joyce Canterbury; Martin Carlos; Phyllis Dibbern, P.T.; Enrique Fernandez, M.D.; Lisa Geyman, M.S.P.T.; Connie Hudson; David Lynch, M.D.; John Newell, M.D.; Robert Quaife, M.D. Jennifer Propst, R.N.; Cynthia Raymond, M.S.; Jane Whalen-Price, P.T.; Kathy Winner, O.T.R.; Martin Zamora, M.D.; Reuben Cherniack, M.D. (Principal Investigator, 1997-2000)

Ohio State University, Columbus, OH: Philip Diaz, M.D. (Principal Investigator); Patrick Ross, M.D. (Co-Principal Investigator); Tina Bees (Principal Clinic Coordinator); Jan Drake; Charles Emery, Ph.D.; Mark Gerhardt, M.D., Ph.D.; Mark King, M.D.; David Rittinger; Mahasti Rittinger.

Saint Louis University, Saint Louis, MO: Keith Naunheim, M.D. (Principal Investigator); Robert Gerber, M.D. (Co-Principal Investigator); Joan Osterloh, R.N., M.S.N. (Principal Clinic Coordinator); Susan Borosh; Willard Chamberlain, D.O.; Sally Frese; Alan Hibbit; Mary Ellen Kleinhenz, M.D.; Gregg Ruppel; Cary Stolar, M.D.; Janice Willey; Francisco Alvarez, M.D. (Co-Principal Investigator, 1999-2002); Cesar Keller, M.D. (Co-Principal Investigator, 1996-2000).

Temple University, Philadelphia, PA: Gerard Criner, M.D. (Principal Investigator) Satoshi Furukawa, M.D. (Co-Principal Investigator); Anne Marie Kuzma, R.N., M.S.N. (Principal Clinic Coordinator); Roger Barnette, M.D.; Neil Brister, M.D. Kevin Carney, R.N., C.C.T.C.; Wissam Chatila, M.D.; Francis Cordova, M.D Gilbert D'Alonzo, D.O.; Michael Keresztury, M.D.; Karen Kirsch; Chul Kwak M.D.; Kathy Lautensack, R.N., B.S.N.; Madelina Lorenzon, C.P.F.T.; Ubaldo Martin M.D.; Peter Rising, M.S.; Scott Schartel, M.D.; John Travaline, M.D.; Gwendolyn Vance, R.N., C.C.T.C.; Phillip Boiselle, M.D. (1997-2000); Gerald O'Brien, M.D. (1997-2000).

University of California, San Diego, San Diego, CA: Andrew Ries, M.D., M.P.H. (Principal Investigator); Robert Kaplan, Ph.D. (Co-Principal Investigator); Catherine Ramirez, B.S., R.C.P. (Principal Clinic Coordinator); David Frankville, M.D.; Pau Friedman, M.D.; James Harrell, M.D.; Jeffery Johnson; David Kapelanski, M.D.; David Kupferberg, M.D., M.P.H.; Catherine Larsen, M.P.H.; Trina Limberg, R.R.T.; Michael Magliocca, R.N., C.N.P.; Frank J. Papatheofanis, M.D., Ph.D.; Dawn SassiDambron, R.N.; Melissa Weeks.

University of Maryland at Baltimore, Baltimore, MD in consortium with Johns Hopkins Hospital, Baltimore, MD: Mark Krasna, M.D. (Principal Investigator); Henry Fessler, M.D. (Co-Principal Investigator); Iris Moskowitz (Principal Clinic Coordinator); Timothy Gilbert, M.D.; Jonathan Orens, M.D.; Steven Scharf, M.D., Ph.D.; David Shade; Stanley Siegelman, M.D.; Kenneth Silver, M.D.; Clarence Weir; Charles White, M.D.

University of Michigan, Ann Arbor, MI: Fernando Martinez, M.D. (Principal Investigator); Mark lannettoni, M.D. (Co-Principal Investigator); Catherine Meldrum, B.S.N R.N., C.C.R.N. (Principal Clinic Coordinator); William Bria, M.D.; Kelly Campbell; Paul Christensen, M.D.; Kevin Flaherty, M.D.; Steven Gay, M.D.; Paramjit Gill, R.N.; Paul Kazanjian, M.D.; Ella Kazerooni, M.D.; Vivian Knieper; Tammy Ojo, M.D.; Lewis Poole Leslie Quint, M.D.; Paul Rysso; Thomas Sisson, M.D.; Mercedes True; Brian Woodcock, M.D.; Lori Zaremba, R.N.

University of Pennsylvania, Philadelphia, PA: Larry Kaiser, M.D. (Principal Investigator); John Hansen-Flaschen, M.D. (Co-Principal Investigator); Mary Louise Dempsey, B.S.N., R.N. (Principal Clinic Coordinator); Abass Alavi, M.D.; Theresa Alcorn, Selim Arcasoy, M.D.; Judith Aronchick, M.D.; Stanley Aukberg, M.D.; Bryan Benedict, R.R.T.; Susan Craemer, B.S., R.R.T., C.P.F.T.; Ron Daniele, M.D.; Jeffrey Edelman, M.D.; Warren Gefter, M.D.; Laura Kotler-Klein, M.S.S.; Robert Kotloff,
M.D.; David Lipson, M.D.; Wallace Miller, Jr., M.D.; Richard O'Connell, R.P.F.T.; Staci Opelman, M.S.W.; Harold Palevsky, M.D.; William Russell, R.P.F.T.; Heather Sheaffer, M.S.W.; Rodney Simcox, B.S.R.T., R.R.T.; Susanne Snedeker, R.R.T., C.P.F.T.; Jennifer Stone-Wynne, M.S.W.; Gregory Tino, M.D.; Peter Wahl; James Walter, R.P. F.T.; Patricia Ward; David Zisman, M.D.; James Mendez, M.S.N., C.R.N.P. (19972001); Angela Wurster, M.S.N., C.R.N.P. (1997-1999).

University of Pittsburgh, Pittsburgh, PA: Frank Sciurba, M.D. (Principal Investigator); James Luketich, M.D. (Co-Principal Investigator); Colleen Witt, M.S. (Principal Clinic Coordinator); Gerald Ayres; Michael Donahoe, M.D.; Carl Fuhrman, M.D.; Robert Hoffman, M.D.; Joan Lacomis, M.D.; Joan Sexton; William Slivka; Diane Strollo, M.D.; Erin Sullivan, M.D.; Tomeka Simon; Catherine Wrona, R.N., B.S.N.; Gerene Bauldoff, R.N., M.S.N. (1997-2000); Manuel Brown, M.D. (1997-2002); Elisabeth George, R.N., M.S.N. (Principal Clinic Coordinator, 1997-2001); Robert Keenan, M.D. (Co-Principal Investigator, 1997-2000); Theodore Kopp, M.S. (1997-1999); Laurie Silfies (1997-2001).

University of Washington, Seattle, WA: Joshua Benditt, M.D. (Principal Investigator), Douglas Wood, M.D. (Co-Principal Investigator); Margaret Snyder, M.N. (Principal Clinic Coordinator); Kymberley Anable; Nancy Battaglia; Louie Boitano; Andrew Bowdle, M.D.; Leighton Chan, M.D.; Cindy Chwalik; Bruce Culver, M.D.; Thurman Gillespy, M.D.; David Godwin, M.D.; Jeanne Hoffman; Andra Ibrahim, M.D.; Diane Lockhart; Stephen Marglin, M.D.; Kenneth Martay, M.D.; Patricia McDowell; Donald Oxorn, M.D.; Liz Roessler; Michelle Toshima; Susan Golden (1998-2000)

\section{Other Participants}

Agency for Healthcare Research and Quality, Rockville, MD: Lynn Bosco, M.D., M.P. H.; Yen-Pin Chiang, Ph.D.; Carolyn Clancy, M.D.; Harry Handelsman, D.O.

Centers for Medicare and Medicaid Services, Baltimore, MD: Steven M. Berkowitz, Ph.D.; Tanisha Carino, Ph.D.; Joe Chin, M.D.; JoAnna Baldwin; Karen McVearry Anthony Norris; Sarah Shirey; Claudette Sikora; Steven Sheingold, Ph.D. (19972004).

Coordinating Center, Johns Hopkins University, Baltimore, MD: Steven Piantadosi, M.D., Ph.D. (Principal Investigator); James Tonascia, Ph.D. (Co-Principal Investigator); Patricia Belt; Amanda Blackford, Sc.M.; Karen Collins; Betty Collison; Ryan Colvin, M.P.H.; John Dodge; Michele Donithan, M.H.S.; Vera Edmonds; Gregory L. Foster, M.A.; Julie Fuller; Judith Harle; Rosetta Jackson; Shing Lee, Sc.M.; Charlene Levine; Hope Livingston; Jill Meinert; Jennifer Meyers; Deborah Nowakowski; Kapreena Owens; Shangqian Qi, M.D.; Michael Smith; Brett Simon, M.D.; Paul Smith; Alice Sternberg, Sc.M.; Mark Van Natta, M.H.S.; Laura Wilson, Sc.M.; Robert Wise, M.D.

Cost Effectiveness Subcommittee: Robert M. Kaplan, Ph.D. (Chair); I. Sanford Schwartz, M.D. (Co-Chair); Yen-Pin Chiang, Ph.D.; Marianne C. Fahs, Ph.D.; A. Mark Fendrick, M.D.; Alan J. Moskowitz, M.D.; Dev Pathak, Ph.D.; Scott Ramsey, M.D., Ph.D.; Steven Sheingold, Ph.D.; A. Laurie Shroyer, Ph.D.; Judith Wagner, Ph.D.; Roger Yusen, M.D.

Cost Effectiveness Data Center, Fred Hutchinson Cancer Research Center, Seattle, WA: Scott Ramsey, M.D., Ph.D. (Principal Investigator); Ruth Etzioni, Ph.D.; Sean Sullivan, Ph.D.; Douglas Wood, M.D.; Thomas Schroeder, M.A.; Karma Kreizenbeck; Kristin Berry, M.S.; Nadia Howlader, M.S.

CT Scan Image Storage and Analysis Center, University of lowa, lowa City, IA: Eric Hoffman, Ph.D. (Principal Investigator); Janice Cook-Granroth, B.S.; Angela Delsing, R.T.; Junfeng Guo, Ph.D.; Geoffrey McLennan, M.D.; Brian Mullan, M.D.; Chris Piker, B.S.; Joseph Reinhardt, Ph.D.; Blake Wood; Jered Sieren, R.T.R.; William Stanford, M.D.

Data and Safety Monitoring Board: John A. Waldhausen, M.D. (Chair); Gordon Bernard, M.D.; David DeMets, Ph.D.; Mark Ferguson, M.D.; Eddie Hoover, M.D.; Robert Levine, M.D.; Donald Mahler, M.D.; A. John McSweeny, Ph.D.; Jeanine Wiener-Kronish, M.D.; O. Dale Williams, Ph.D.; Magdy Younes, M.D.

Marketing Center, Temple University, Philadelphia, PA: Gerard Criner, M.D. (Principal Investigator); Charles Soltoff, M.B.A

Project Office, National Heart, Lung, and Blood Institute, Bethesda, MD: Gail Weinmann, M.D. (Project Officer); Joanne Deshler (Contracting Officer); Dean Follmann, Ph.D.; James Kiley, Ph.D.; Margaret Wu, Ph.D. (1996-2001).

\section{References}

1. Chatila WM, Thomashow BM, Minai OA, Criner GJ, Make BJ. Comorbidities in chronic obstructive pulmonary disease. Proc Am Thorac Soc 2008:5:549-555.

2. Fabbri LM, Luppi F, Beghe B, Rabe KF. Complex chronic comorbidities of COPD. Eur Respir J 2008;31:204-212.

3. Gan WQ, Man SF, Senthilselvan A, Sin DD. Association between chronic obstructive pulmonary disease and systemic inflammation: a systematic review and a meta-analysis. Thorax 2004;59:574-580. 
4. Schols AM, Fredrix EW, Soeters PB, Westerterp KR, Wouters EF. Resting energy expenditure in patients with chronic obstructive pulmonary disease. Am J Clin Nutr 1991;54:983-987.

5. Wagner PD. Possible mechanisms underlying the development of cachexia in COPD. Eur Respir J 2008;31:492-501.

6. Mineo D, Ambrogi V, Frasca L, Cufari ME, Pompeo E, Mineo TC. Effects of lung volume reduction surgery for emphysema on glycolipidic hormones. Chest 2008;134:30-37.

7. Schols AM, Slangen J, Volovics L, Wouters EF. Weight loss is a reversible factor in the prognosis of chronic obstructive pulmonary disease. Am J Respir Crit Care Med 1998;157:1791-1797.

8. Vestbo J, Prescott E, Almdal T, Dahl M, Nordestgaard BG, Andersen T, Sorensen TI, Lange P. Body mass, fat-free body mass, and prognosis in patients with chronic obstructive pulmonary disease from a random population sample: findings from the Copenhagen City Heart Study. Am J Respir Crit Care Med 2006;173:79-83.

9. Celli BR, Cote CG, Marin JM, Casanova C, Montes de Oca M, Mendez RA, Pinto Plata V, Cabral HJ. The body-mass index, airflow obstruction, dyspnea, and exercise capacity index in chronic obstructive pulmonary disease. N Engl J Med 2004;350:1005-1012.

10. National Emphysema Treatment Trial Research Group. A randomized trial comparing lung volume-reduction surgery with medical therapy for severe emphysema. N Engl J Med 2003;348:2059-2073.

11. Mineo D, Ambrogi V, Cufari ME, Gambardella S, Pignotti L, Pompeo E, Mineo TC. Variations of inflammatory mediators and $\alpha_{1}$-antitrypsin levels after lung volume reduction surgery for emphysema. Am J Respir Crit Care Med 2010;181:806-814.

12. Kretschman DM, Kim V, Pechulis RM, Criner GJ; on behalf of the National Emphysema Treatement Trial Research Group. Effect of lung volume reduction surgery on body mass index [abstract]. Am J Respir Crit Care Med 2009;179:A2915.

13. National Emphysema Treatment Trial Research Group. Patients at high risk of death after lung-volume-reduction surgery. N Engl J Med 2001; 345:1075-1083.

14. Wallace JI, Schwartz RS, LaCroix AZ, Uhlmann RF, Pearlman RA. Involuntary weight loss in older outpatients: incidence and clinical significance. J Am Geriatr Soc 1995;43:329-337.

15. Wing RR, Lang W, Wadden TA, Safford M, Knowler WC, Bertoni AG, Hill JO, Brancati FL, Peters A, Wagenknecht L; Look AHEAD Research Group. Benefits of modest weight loss in improving cardiovascular risk factors in overweight and obese individuals with type 2 diabetes. Diabetes Care 2011;34:1481-1486.

16. Sun XG, Hansen JE, Garatachea N, Storer TW, Wasserman K. Ventilatory efficiency during exercise in healthy subjects. Am J Respir Crit Care Med 2002;166:1443-1448.

17. Mineo TC, Pompeo E, Mineo D, Ambrogi V, Ciarapica D, Polito A. Resting energy expenditure and metabolic changes after lung volume reduction surgery for emphysema. Ann Thorac Surg 2006;82:1205-1211.
18. Schols AM, Soeters PB, Dingemans AM, Mostert R, Frantzen PJ, Wouters EF. Prevalence and characteristics of nutritional depletion in patients with stable COPD eligible for pulmonary rehabilitation. Am Rev Respir Dis 1993;147:1151-1156.

19. Engelen MP, Schols AM, Baken WC, Wesseling GJ, Wouters EF. Nutritional depletion in relation to respiratory and peripheral skeletal muscle function in out-patients with COPD. Eur Respir J 1994;7:1793-1797.

20. Sergi G, Coin A, Marin S, Vianello A, Manzan A, Peruzza S, Inelmen EM, Busetto L, Mulone S, Enzi G. Body composition and resting energy expenditure in elderly male patients with chronic obstructive pulmonary disease. Respir Med 2006;100:1918-1924.

21. Creutzberg EC, Casaburi R. Endocrinological disturbances in chronic obstructive pulmonary disease. Eur Respir J Suppl 2003;46:76s-80s.

22. Koehler F, Doehner W, Hoernig S, Witt C, Anker SD, John M. Anorexia in chronic obstructive pulmonary disease: association to cachexia and hormonal derangement. Int J Cardiol 2007;119:83-89.

23. Schols AM, Soeters PB, Mostert R, Saris WH, Wouters EF. Energy balance in chronic obstructive pulmonary disease. Am Rev Respir Dis 1991;143:1248-1252.

24. Di Francia M, Barbier D, Mege JL, Orehek J. Tumor necrosis factor- $\alpha$ levels and weight loss in chronic obstructive pulmonary disease. Am J Respir Crit Care Med 1994;150:1453-1455.

25. Takabatake N, Nakamura H, Abe S, Hino T, Saito H, Yuki H, Kato S, Tomoike H. Circulating leptin in patients with chronic obstructive pulmonary disease. Am J Respir Crit Care Med 1999;159:1215-1219.

26. Broekhuizen R, Grimble RF, Howell WM, Shale DJ, Creutzberg EC, Wouters EF, Schols AM. Pulmonary cachexia, systemic inflammatory profile, and the interleukin $1 \beta-511$ single nucleotide polymorphism. Am J Clin Nutr 2005;82:1059-1064.

27. Van Helvoort HA, Heijdra YF, Thijs HM, Vina J, Wanten GJ, Dekhuijzen PN. Exercise-induced systemic effects in muscle-wasted patients with COPD. Med Sci Sports Exerc 2006;38:1543-1552.

28. Mineo D, Ambrogi V, Lauriola V, Pompeo E, Mineo TC. Recovery of body composition improves long-term outcomes after lung volume reduction surgery for emphysema. Eur Respir J 2010;36:408-416.

29. Kleber FX, Vietzke G, Wernecke KD, Bauer U, Opitz C, Wensel R, Sperfeld A, Glaser S. Impairment of ventilatory efficiency in heart failure: prognostic impact. Circulation 2000;101:2803-2809.

30. Hansen JE, Wasserman K. Pathophysiology of activity limitation in patients with interstitial lung disease. Chest 1996;109:1566-1576.

31. Wasserman K, Hansen JE, Sue DY, Stringer WW, Whipp BJ. Principles of exercise testing and interpretation: including pathophysiology and clinical applications. Philadelphia, PA: Lippincott Williams \&Wilkins; 2005.

32. Criner GJ, Belt P, Sternberg AL, Mosenifar Z, Make BJ, Utz JP, Sciurba F; National Emphysema Treatment Trial Research Group. Effects of lung volume reduction surgery on gas exchange and breathing pattern during maximum exercise. Chest 2009;135:1268-1279. 